\title{
Antecedents of Organizational Performance in Challenging Business Environment: The role of Employee Commitment and Supply Chain Integration
}

\begin{abstract}
Mian Muhammad Atif ${ }^{1}$, Sajjad Nazir ${ }^{2}$, Syed Muhammad Abdullah ${ }^{3}$
Abstract

Businesses in KP region face multidimensional problems and as such they require to be studied within their unique settings. This study is an attempt to understand the link of employee commitment and supply chain integration on organizational performance using structural equation modelling on data collected via questionnaires from employees of FMCGs operating in District Peshawar, Mardan, Noshehra and Swabi. A total of 152 usable responses were received and used for the purpose of study. The results indicate that Employee Commitment is positively and significantly related to Supply Chain Integration and Organizational performance and Supply Chain Integration is positively and significantly related to Organizational Performance. The paper conclude that managers should invest in creating a favourable work environment for the employees and must work towards creating an integrated supply chain to enhance organizational performance. Finally, some venues for further research in the area are presented.
\end{abstract}

Keywords: KP Business Environment, Business Challenges, Supply Chain Management, Employee Commitment, Supply Chain Integration, Organizational Performance, Structural Equation Modelling, Confirmatory Factor Analysis

\section{Introduction}

Competitive advantage has long been argued as the key element for sustained organization performance (see e.g., Porter, 1986). In the past, it was possible for firms to rely on their own capabilities to achieve competitive advantage, however, increased performance and efficiency pressures originating from contemporary business environment have forced firms to look beyond their internal capabilities for

1 National University of Computer $\mathcal{E}$ Emerging Sciences, (FAST-NU), Lahore. Email: mian.ati@@ nu.edu.pk

2 GIK Institute of Engineering Sciences and Technology, Topi.

3 GIK Institute of Engineering Sciences and Technology, Topi.

\begin{tabular}{lll} 
ARTICLE HISTORY & \\
\hline 19 Jul, 2017 Submission Received & 16 Aug, 2017 & First Review \\
\hline 18 Sep, 2017 Revised Version Received & 15 Nov, 2017 & Second Review \\
\hline 24 Nov, 2017 Revised Version Received & 10 Dec, 2017 & Accepted
\end{tabular}


continued survival. Fine (1998) identifies Supply Chain Management (SCM) as one of such areas through which firms have been able to enhance their competitiveness. The term SCM refer to planning and control of business activities from raw material supplies to final delivery to end-user that can maximize consumer value (Harrison $\&$ Van Hoek, 2005). There are many studies that have explored the role of SCM in organization performance in international context (see e.g., Ageron, Gunasekaran, \& Spalanzani, 2012; Alfalla-Luque, Marin-Garcia, \& Medina-Lopez, 2015; Barratt, 2004; Crum, Poist, Carter, \& Liane Easton, 2011; Gimenez \& Ventura, 2003; Lambert, Cooper, \& Pagh, 1998; Shub \& Stonebraker, 2009; Stevens, 1989). However, SCM has largely remained understudied in the context of business challenges in Khyber Pakhtunkhwa (KP) region.

The business challenges in KP region are multidimensional that not only includes problems origination from terrorism but also costly power, capacity constraints, supply bottlenecks, lack of skilled labour and underdeveloped logistical and operational infrastructure. Keeping in view these challenges effective supply chain management becomes even more important for KP businesses (Naz, Khan, Hussain, \& Daraz, 2011). To overcome these challenges and to remain competitive business managers need to invest substantial financial resources and time to develop and manage supply chain members. In other words, the firms need to invest in integrating the supply chain operations to remain competitive in the face of increasing globalization and competition from the businesses. Council of Supply Chain Management Professionals (CSCMP) define Supply Chain Integration (SCI) "as the process of linking major business functions and processes within and across companies into a cohesive and high performing business model (CSCMP, 2009 as quoted by Stevens \& Johnson, 2015). Wiengarten, Humphreys, Gimenez, and McIvor (2016) [see also Bowersox, Closs, and Stank (2003); Fawcett, Magnan, and McCarter (2008); Lambert et al. (1998)] argue that SCI is considered to be an important and effective tool that help create efficiencies (Fawcett \& Magnan, 2002; Qrunfleh \& Tarafdar, 2014; Ralston, Blackhurst, Cantor, \& Crum, 2015) to enhance firms' competitiveness (Cao, Huo, Li, \& Zhao, 2015; Frohlich \& Westbrook, 2001) and performance (Cao et al., 2015; Danese \& Bortolotti, 2014; Mackelprang, Robinson, Bernardes, \& Webb, 2014) through cost reduction (Huang, Yen, \& Liu, 2014; Zhao, Huo, Flynn, \& Yeung, 2008). In other words, an integrated supply chain will enable the firm to reduce costs and increase performance delivery thus creating value for end user. There are many enablers of an integrated supply chain (see e.g., Christopher \& Juttner, 2000; Christopher \& Jüttner, 2000 for both academic and practitioner perspectives). Researchers, however, identify the role of employees to be an important aspect and precedent for a successful integration (Alfalla-Luque et al., 2015; Barratt, 2004; Christopher \& Juttner, 2000; Dainty, Millett, \& Briscoe, 2001; Handfield \& Nichols, 2002; Narasimhan \& Kim, 2002; Shub \& 
Stonebraker, 2009). Alfalla-Luque et al. (2015) argue that role of employee commitment is one of the most important aspect that can help create a delivering value chain. Commitment in general is defined as the degree to which an individual is dedicated for a cause or activity. Employee Commitment specifically is defined as the degree to which an employee identifies him/herself with the organization and shares it values and objectives (Meyer, 2014). Thus, it can be argued that Employee Commitment is an important antecedent for supply chain integration because of the extra effort and sensitivity to cause required for developing such lasting relations on the part of the employees. The role of employee commitment specifically in KP region context becomes even more important due to continued and prolonged terrorism incidences.

Based on the discussion above and keeping in view the importance of employee commitment and supply chain integration on organizational performance, this study explores the role of employee commitment and supply chain integration on firm performance of FMCGs operating in KP region through data collected from District Peshawar, Mardan, Nowshehra and Swabi. In the following we will present the related literature and develop the hypotheses for the study followed by the section on methodology adopted for the study and finally present our discussion and conclusion.

\section{Literature Review}

Stock and Boyer (2009), after extensive review of published research on the topic, define Supply Chain Management as "the management of a network of relationships within a firm and between interdependent organizations and business units consisting of material suppliers, purchasing, production facilities, logistics, marketing, and related systems that facilitate the forward and reverse flow of materials, services, finances and information from the original producer to final customer with the benefits of adding value, maximizing profitability through efficiencies, and achieving customer satisfaction" (p. 706). Effectiveness of supply chain can be enhanced substantially by integrating the players and components. According to Stevens (1989) firms realized the value of integrating supply chain quite early and there has been growing consensus between academics and practitioners regarding their importance of integrating suppliers, internal processes and flows and customers [see also Frohlich and Westbrook (2001); Tan (2001)]. Despite research confirming the positive affect of SCI (Prajogo, Oke, \& Olhager, 2016), and its value in firm's sustainability (Flynn, Chan, Zhu, \& $\mathrm{Yu}, 2017$ ); yet it remains puzzling as to what institutes SCI (Autry, Rose, \& Bell, 2014; Fabbe-Costes \& Jahre, 2008) and has been defined and operationalized in a number of ways (Pagell \& Shevchenko, 2014). Traditionally, SCI has been classified into internal integration (II) and external integration (EI). Where II refers to integration of the internal departments within a business and EI include Supplier Integration 
(SI) and Customer Integration (CI) (Cao et al., 2015; Prajogo et al., 2016; Stevens \& Johnson, 2015). Earlier research has remained indecisive about influence of SCI on organizational performance (see e.g., Li, Ragu-Nathan, Ragu-Nathan, \& Subba Rao, 2006; Swink, Narasimhan, \& Wang, 2007) thus requiring further investigation to understand its full influence (Stevens \& Johnson, 2015).

Therefore, keeping in view the discussion presented above, our first hypotheses relate to the relationship between SCI and organizational performance and we argue that SCI will have positive and significant relationship with organizational performance.

Alfalla-Luque et al. (2015) argue for inclusion of Employee Commitment (EC) as one of the variable through which the study of SCI and Organizational Performance can be enhanced. Beside the above, the role of EC, as argued earlier, is important for our purposes because of prolonged and continued incidences of terrorism in KP region, which has been arguably created a complex and stressful job environment (Abbas, Hassan, \& Ali, 2017; Ali, Mahsud, \& Khan, 2016; Bader, Reade, \& Froese, 2016). According to Abbas et al. (2017) the terrorism incidences in KP region has created severe mental and physical health issues for residents including Post Traumatic Stress Disorder (PTSD). PTSD and other psychological issues have been found to impact almost all aspects of personal and professional life (see also Ali et al., 2016). Under such conditions it becomes increasingly difficult for the organizations to achieve efficient operation levels (Bardoel, Pettit, De Cieri, \& McMillan, 2014). Keeping in view the specific challenges the employees of $\mathrm{KP}$ region face, we also wanted to study the role of EC in organizational performance.

Meyer, Allen, and Smith (1993) describe EC as the degree to which an employee connects him/herself with the firms' goals and values (see also Fields \& Thacker, 1992; Mowday, Steers, \& Porter, 1979). In other words, an employee with high level of EC will own the values and goals of the organization and will put greater efforts to achieve them. Kuo, Ho, Lin, and Lai (2010) argue that high employee commitment will result in employee achieving greater independence, swiftly develop core competencies and tend to be more accepting of tasks beyond their job description. All these attributes help organization achieve greater efficiencies and effectiveness in goal attainment.

As argued earlier, EC in the context of business environment of KP becomes even more important because of the stressful environment emanating from the business challenges of the region. Within the Human Resource literature, the relationship between EC and organization performance has been studied extensively from a variety of aspects including its direct, mediating and moderating role (see e.g., Alfalla-Luque, Marín-García, \& Medina-López, 2012; Elorza, Aritzeta, \& Ayestaran, 2011; Guest \& Conway, 2002; Patterson, West, Lawthom, \& Nickell, 1997). According to 
Elorza et al. (2011) the relationship between EC and organization performance is clearly evident and the higher an employee level of commitment the more likely an organization success.

Based on the discussion above, our second hypothesis relate to EC and Organizational Performance and we argue that EC is positively and significantly related to organizational performance.

It is generally argued that researchers have mostly studied SCM and SCI from the operations management perspective such as Total Quality Management, Just in Time and similar topics and rarely from a soft perspective such as Human Resource Management etc. (see e.g., Alfalla-Luque et al., 2015; Alfalla-Luque et al., 2012; Cadden, Marshall, \& Cao, 2013; Estampe, Lamouri, Paris, \& Brahim-Djelloul, 2013; Shub $\&$ Stonebraker, 2009). According to Jin, Vonderembse, Ragu-Nathan, and Smith (2014) there exists a gap in literature when it comes to studying the antecedents of SCI. Alfalla-Luque et al. (2015) similarly argues that there are many researches which have studied the role of SCI and EC in organizational performance independently but very few that have used the extensive model to study the aspects of HRM as antecedent of SCI.

In our case, specifically for $\mathrm{KP}$ region, as argued earlier the role of $\mathrm{EC}$ becomes an important antecedent of SCI and we propose that EC will have a positive and significant relationship with organizational performance. This relationship has been studied before by researchers such as Alfalla-Luque et al. (2015) and Alfalla-Luque et al. (2012); Cao et al. (2015); Mackelprang et al. (2014); Shub and Stonebraker (2009).

Based on the discussions above, we can derive the following theoretical model for our research.

After presenting the relevant literature and theoretical framework, in the follow-

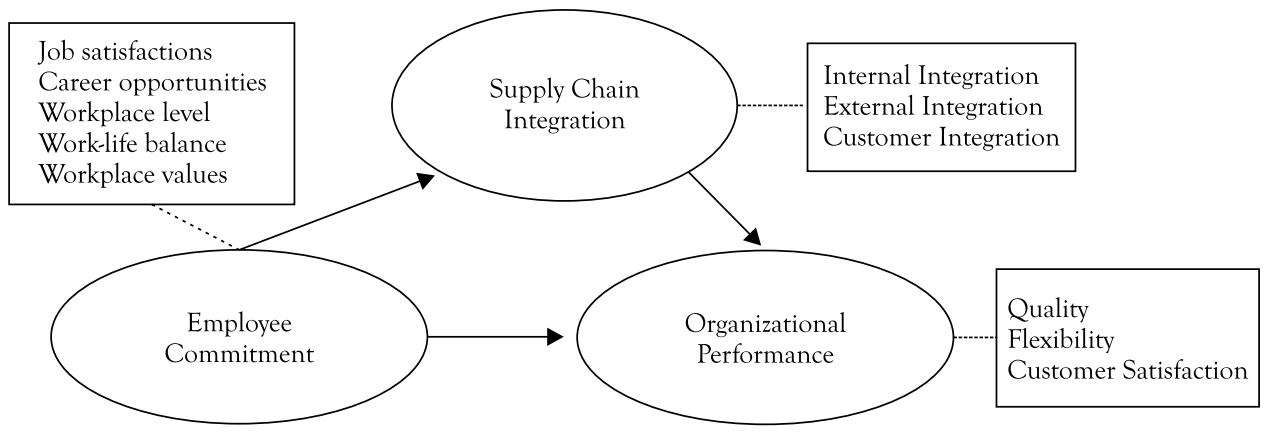

Figure 1: Theoretical Framework: Employee Commitment, Supply Chain Integration and Organizational Performance 
ing we will describe our methodology and test the hypothesis generated and provide our conclusion.

\section{Methodology}

Following Alfalla-Luque et al. (2015) we used HPM third round questionnaire to collect data for this study. Data was collected from current employees of FMCGs operating in KP region, specifically District Peshawar, Nowshehra, Mardan and Swabi. The use of an already established questionnaire was preferred over making a new because its validity, reliability and internal consistency had already been established. The questionnaire consisted of 25 questions and was divided into four sections with five questions related to demographics, five questions to measure $\mathrm{EC}$, ten questions to measure SCI through its components internal and external integration and finally five questions related to organizational performance. Besides demographics all remaining questions were asked on a five-point Likert scale. Reliability of the constructs measurement were obtained using Cronbach's alpha and all constructs were found to be reliably measured. Following are the reliability statistics for the questionnaire items in pilot testing.

Table 1: Reliability Statistics $(\mathrm{N}=20)$

\begin{tabular}{|c|c|c|}
\hline Construct & No. of item & Cronbach Alpha \\
\hline Employee Commitment (EC) & 5 & 0.861 \\
\hline Supply Chain Integration (SCI) & 10 & 0.877 \\
\hline Organizational Performance & 5 & 0.859 \\
\hline
\end{tabular}

A total of 240 questionnaire were distributed to respondents chosen using stratified convenience sampling in order to solicit equal responses from all the four districts under study. The average response rate was approximately $65 \%$ of which further four responses were discarded for a variety of reasons the remaining 152 were used for the purpose of the study.

Table 2: Sample Demographics $(\mathrm{N}=152)$

\begin{tabular}{|c|c|c|}
\hline District & Distributed & No. of usable Responses \\
\hline Peshawar & 60 & 40 \\
\hline Swabi & 60 & 45 \\
\hline Nowshehra & 60 & 35 \\
\hline Mardan & 60 & 32 \\
\hline Total & 240 & 152 \\
\hline
\end{tabular}


While the overall sample size is generally dependent upon the population under study, however, Anderson and Gerbing (1988) suggest that a total of 100 responses is acceptable in Structural Equation Modelling (SEM) (see also Hair, Black, Babin, $\&$ Anderson, 2010; Kline, 2011). After establishing the minimum required sample size and confirming the validity of the data, we turned to hypotheses testing through Confirmatory Factor Analysis (CFA) in SEM. We considered SEM to be preferable over other linear regression model as it can be used for both estimating and testing interrelationships between constructs while at the same time it can overcome the issue of measure-specific error (Weston, 2006). Two-step process is required to analyse construct relationships using SEM, step 1 involves testing the measurement model whereas step two requires testing the structural model (Anderson \& Gerbing, 1988). In order to accurately assess the overall model-fit in SEM, it is also imperative to observe a correlation, for the reason that constructs should be correlated to be able to test a path/s among other constructs (Hair et al., 2010). Thus, we calculated correlation for all the studied variables, including EC, SCI i.e. Internal Integration, External Integration and Customer Integration and Organizational Performance [matrix is presented in Table 3].

Table 3: Descriptive Statistics, Correlation Coefficients amongst Study Variables $(\mathrm{N}=152)$

\begin{tabular}{|c|c|c|c|c|c|}
\hline \multirow[t]{2}{*}{ Variables } & \multirow[t]{2}{*}{$\mathrm{EC}$} & \multicolumn{3}{|c|}{ Supply Chain Integration } & \multirow{2}{*}{$\begin{array}{l}\text { Organization- } \\
\text { al Perfor- } \\
\text { mance }\end{array}$} \\
\hline & & EI & II & CI & \\
\hline $\begin{array}{c}\text { Employee Commit- } \\
\text { ment }\end{array}$ & $(0.798)$ & & & & \\
\hline External Integration & $0.810^{* *}$ & $(0.832)$ & & & \\
\hline Internal Integration & $0.714^{*}$ & $0.760^{* *}$ & $(0.843)$ & & \\
\hline $\begin{array}{c}\text { Customer Integra- } \\
\text { tion }\end{array}$ & $0.891^{* *}$ & $0.856^{* *}$ & $0.832^{* *}$ & $(0.788)$ & \\
\hline $\begin{array}{l}\text { Organizational } \\
\text { Performance }\end{array}$ & $0.755^{* *}$ & 0.778 & $0.787^{* *}$ & $0.848^{* *}$ & $(0.871)$ \\
\hline
\end{tabular}

Note: ${ }^{*}$ and ${ }^{* *}$ indicate significance at the $5 \%$ and $1 \%$ levels, respectively. Numbers in parentheses are mean-square-root of AVE.

According to Nunnally (1978) SEM analysis requires parameter assessment, evaluation of fit, model specification, sample sizing and finally interpretation and evaluation (see also Byrne, 2013). In order to assess model's construct validity, we used Confirmatory Factor Analysis (CFA) in SEM. Byrne (2013) suggests that in order to assess goodness of fit the Standard factor loading of an indicator should be a mini- 
mum of 0.7 is considered acceptable, similarly Construct Reliability and Cronbach's Alpha should be a minimum of 0.7, whereas Convergent Reliability, measure through Average Variance Extracted should have a minimum value of 0.5 [see also, Hair et al. (2010); Fornell and Larcker (1981) and Gaertner (2000)].

When we entered our model for testing under CFA, there were no issues regarding the validity and reliability. The resultant figures of factor loadings, the composite reliability, the construct loading and the average variance extracted are shown in table 4. All factor loadings are above 0.7 and there isn't a single value that is greater than 1 .

Table 4: Confirmatory Factor Analysis

\begin{tabular}{|c|c|c|c|c|}
\hline Construct Measured & $\begin{array}{l}\text { Standard Fac- } \\
\text { tor Loading }\end{array}$ & $\begin{array}{l}\text { Construct Re- } \\
\text { liability (CR) }\end{array}$ & $\begin{array}{l}\text { Average Vari- } \\
\text { ance Extracted }\end{array}$ & $\begin{array}{c}\text { Cronbach's } \\
\text { Alpha }\end{array}$ \\
\hline Employee Commitment & & 0.817 & 0.732 & 0.719 \\
\hline $\begin{array}{l}\text { EC1: I am proud to tell } \\
\text { others that I am part of this } \\
\text { organization }\end{array}$ & 0.810 & & & \\
\hline $\begin{array}{c}\text { EC2: I am proud of my } \\
\text { decision to join this organi- } \\
\text { zation }\end{array}$ & 0.701 & & & \\
\hline $\begin{array}{l}\text { EC3: I speak highly of my } \\
\text { organization to others }\end{array}$ & 0.865 & & & \\
\hline $\begin{array}{l}\text { EC4: I find it difficult to } \\
\text { agree with this organiza- } \\
\text { tion's policies relating to its } \\
\text { employees }\end{array}$ & 0.605 & & & \\
\hline $\begin{array}{l}\text { EC5: Major satisfaction in } \\
\text { my life comes from my job }\end{array}$ & 0.554 & & & \\
\hline \multicolumn{5}{|l|}{ Supply Chain Integration } \\
\hline External Integration & & 0.827 & 0.739 & 0.781 \\
\hline $\begin{array}{l}\text { SCI1: We work as a partner } \\
\text { with our suppliers }\end{array}$ & 0.716 & & & \\
\hline $\begin{array}{l}\mathrm{SCI} 2 \text { : We believe that coop- } \\
\text { erative relationship will lead } \\
\text { to better performance }\end{array}$ & 0.724 & & & \\
\hline $\begin{array}{l}\text { SCI3: We maintain cooper- } \\
\text { ative relationships with our } \\
\text { supplier }\end{array}$ & 0.806 & & & \\
\hline $\begin{array}{l}\text { SCI4: We do our best to } \\
\text { establish long term relation- } \\
\text { ship with our suppliers }\end{array}$ & 0.798 & & & \\
\hline
\end{tabular}




\begin{tabular}{|c|c|c|c|c|}
\hline $\begin{array}{l}\text { SCI5: Our suppliers strive } \\
\text { to establish long term rela- } \\
\text { tionship with us } \\
\end{array}$ & 0.812 & & & \\
\hline Internal Integration & & 0.788 & 0.876 & 0.810 \\
\hline $\begin{array}{l}\text { SCI6: Different depart- } \\
\text { ments communicate fre- } \\
\text { quently with each other }\end{array}$ & 0.789 & & & \\
\hline $\begin{array}{l}\text { SCI7: Generally speaking } \\
\text { everyone in the organization } \\
\text { works well together }\end{array}$ & 0.763 & & & \\
\hline $\begin{array}{l}\text { SCI8: Management works } \\
\text { together well on all import- } \\
\text { ant decisions }\end{array}$ & 0.644 & & & \\
\hline Customer Integration & & 0.852 & 0.806 & 0.782 \\
\hline $\begin{array}{l}\text { SCI9: We frequently are } \\
\text { in close contact with our } \\
\text { customers }\end{array}$ & 0.832 & & & \\
\hline $\begin{array}{l}\text { SCI10: Our customer } \\
\text { regularly give feedback on } \\
\text { our quality and delivery } \\
\text { performance }\end{array}$ & 0.617 & & & \\
\hline Organizational Performance & & 0.834 & 0.758 & 0.845 \\
\hline $\begin{array}{l}\text { OP1: Our deliveries are } \\
\text { always on time }\end{array}$ & 0.818 & & & \\
\hline $\begin{array}{l}\text { OP2: We have flexibility to } \\
\text { change volume }\end{array}$ & 0.809 & & & \\
\hline $\begin{array}{l}\text { OP3: Our customers are } \\
\text { pleased with the quality } \\
\text { of product and services } \\
\text { provided }\end{array}$ & 0.804 & & & \\
\hline $\begin{array}{c}\text { OP4: Customer standards } \\
\text { are always met by our orga- } \\
\text { nization }\end{array}$ & 0.795 & & & \\
\hline $\begin{array}{l}\text { OP5: Our customers are } \\
\text { happy with our responsive- } \\
\text { ness to their issues }\end{array}$ & 0.510 & & & \\
\hline
\end{tabular}


As can be seen in the above table, all of the latent variables i.e. EC, SCI and organizational performance and their respective indicators besides EC4 and EC5, SCI8 and SCI10, and OP5 have standard factor loading greater than 0.7, which makes it significant for the purpose of final model testing and fit. Since the value of standard factor loading for EC4 and EC5, SCI8 and SCI10 along with OP5 is below 0.7, therefore these indicators will be ignored for the purpose of model testing. Similarly, the CR is significant for all the latent variables and are accepted for the final model. The latent variables convergent validity measured through AVE is also within the acceptable range, i.e. greater than 0.5. The table also indicate that Cronbach's Alpha for the latent variables are higher than 0.7 and as such represent a valid measure for the construct and will be usable for the purpose of model testing.

After testing the data and establishing the fit, in the following section we will discuss our final results and provide a conclusion to the research.

\section{Discussion and Conclusion}

In literature review, we studied the relevant literature and established our hypotheses for the study. Our first hypothesis was related to SCI and Organizational performance, where we stated that "SCI will have a positive and significant relationship with Organizational performance". The results of the hypothesis test are presented in the table below.

Table 5: Path Coefficients and Hypothesis Testing (H1: SCI and Organizational Performance)

\begin{tabular}{|c|c|c|c|c|c|}
\hline Hypothesis & Path & $\begin{array}{c}\text { Standardized regression } \\
\text { weight }\end{array}$ & T. Value & P. Value & Result \\
\hline H1 & $\begin{array}{c}\text { SCI } \rightarrow \text { Organiza- } \\
\text { tional Performance }\end{array}$ & 0.349 & 9.036 & 0.000 & Supported \\
\hline
\end{tabular}

Hypothesis $\mathrm{H} 1$ is supported in the study as its $\mathrm{P}$. value is less than 0.05 and having a T. value of great than 1.98 which indicates a positive relation between the variables. Earlier research in the area has remained inconclusive see e.g. the work of Leuschner, Rogers, and Charvet (2013) and Sofyalığlu and Öztürk (2012) for a meta-analysis on the role of SCI on organizational performance. Our results are in accordance with the findings of Li et al. (2006) and Alfalla-Luque et al. (2015); (see also Christopher \& Juttner, 2000; Gimenez \& Ventura, 2003). Our results are however inconsistent with the findings of Hertz (2001); Swink et al. (2007) and Jin et al. (2014). We argue that because of the specific business environmental circumstances of KP region, the role of supply chain integration in performance carry additional significance. We argue that in the challenging business environment $\mathrm{SCI}$ can further help in providing 
the mechanism through which the organizational can foster a culture of increased responsiveness to customer requirements as well as efficiently integrate with suppliers which in turn enables efficient and effective operations. Thus increased and enhanced input towards overall organizational performance.

Our second hypothesis dealt with the relationship of EC with organizational performance. We stated that "EC will have a positive and significant relationship with Organizational performance". The results of this hypothesis are presented in the table below.

Table 6: Path Coefficients and Hypothesis Testing (H2: EC and Organizational Performance)

\begin{tabular}{|c|c|c|c|c|c|}
\hline Hypothesis & Path & $\begin{array}{c}\text { Standardized regression } \\
\text { weight }\end{array}$ & T. Value & P. Value & Result \\
\hline H2 & $\begin{array}{c}\text { EC } \rightarrow \text { Organiza- } \\
\text { tional Performance }\end{array}$ & 0.254 & 7.924 & 0.000 & Supported \\
\hline
\end{tabular}

Our second hypothesis is also supported with p. value of 0.000 and T. value of 7.924 which establishes a significant and positive relationship of EC with organizational performance. Extensive studies have been carried out on the topic, and our results are consistent with the results of Kuo et al. (2010); Nishii, Lepak, and Schneider (2008) and Samad (2013). We conclude that in the business environment of KP which is plagued by many logistical and supply chain bottlenecks, it is imperative that a strongly committed employee works for the organization who can take the extra step to cover for the supply chain deficiencies through personal interaction and commitment with the organization. Thus, in KP business environment, due to specific and measurable challenges faced by employees, it makes sense that the higher the employee commitment the higher his input towards the organizational cause and as such we see a positive and significant relationship of EC with organizational performance.

We stated in our third hypothesis that $\mathrm{EC}$ will have a positive and significant relationship with SCI. The results of this hypothesis test are presented in the below table.

Table 7: Path Coefficients and Hypothesis Testing (H3: EC and SCI)

\begin{tabular}{|c|c|c|c|c|c|}
\hline Hypothesis & Path & $\begin{array}{c}\text { Standardized regression } \\
\text { weight }\end{array}$ & T. Value & P. Value & Result \\
\hline H3 & EC $\rightarrow$ SCI & 0.410 & 8.924 & 0.000 & Supported \\
\hline
\end{tabular}


Based on the table above, our third hypothesis is also accepted and we found the relationship between EC and SCI to be both positively and significantly related to each other, which means the higher level of EC and organization enjoys the more chances that the internal and external elements of its supply chain are integrated. Overall the relationship between the two has remained inconclusive with some authors (Alfalla-Luque et al., 2015; Alfalla-Luque et al., 2012; Fawcett et al., 2008; Gimenez \& Ventura, 2003) find a positive relationship while others such as Gowen Iii and Tallon (2003); Pandey, Bhattacharyya, and Kaur (2012) and Vanichchinchai (2012) do not find a significant relationship between the two. We argue that the role of EC in SCI in KP context is both theoretically and practically important because of the additional burden on employees to cater with the problems arising from terrorism and supply chain bottlenecks.

Below is our final model for the study.

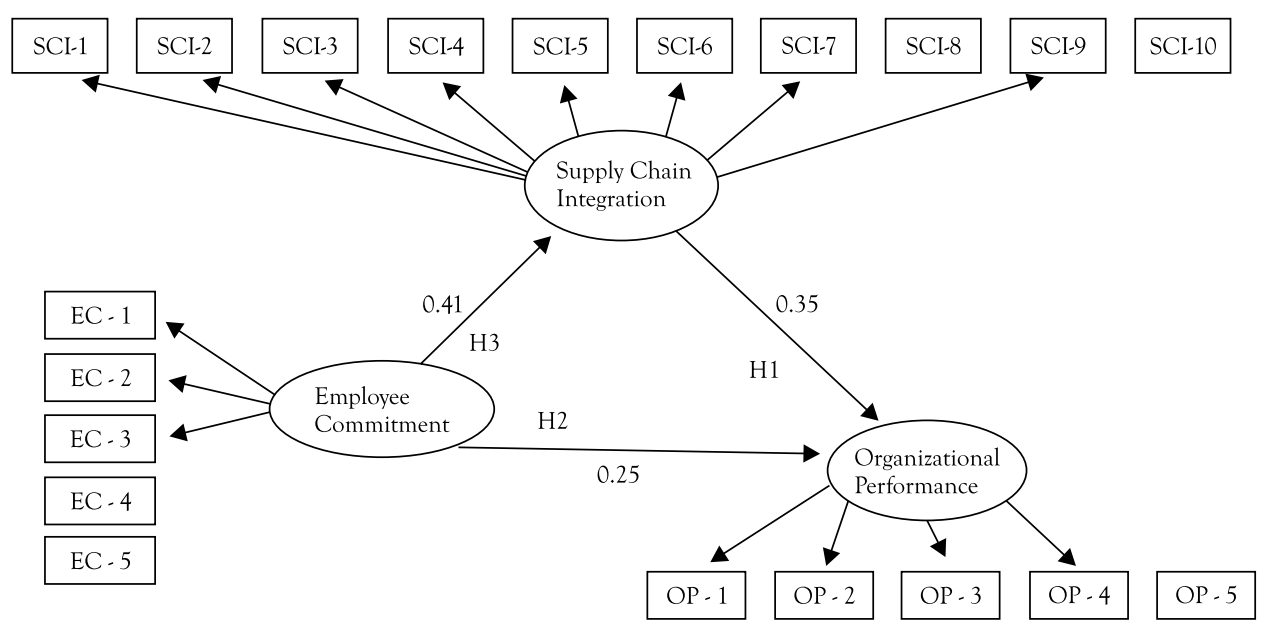

EC - 4, EC - 5, SCI -8, SCI - 10 and OP - 5 ignored

Figure 2: Final Model

\section{Research Significance, Implication and Future Research Opportunities}

We started this paper with a discussion about the importance of studying the business environment of $\mathrm{KP}$ region, due to the unique challenges faced by businesses and residents in general. The main purpose of this paper was to assess the role of Employee Commitment and Supply Chain integration on organizational performance in the business environment of $\mathrm{KP}$ region as a proxy for a challenging business environment. Based on our observations and the relevant literature, we developed three hypotheses to test the relationships of these constructs. Our analysis indicate that 
EC has positive and significant relationship with both Supply Chain Integration and Organizational Performance. Similarly, we were able to test the relationship of Supply Chain Integration with Organizational Performance and found that both are significantly and positively related. In the discussion and conclusion section of this paper, we discussed in detail the specific implications of the unique business challenges in KP towards EC, SCI and organizational performance and their inter-relationship.

Our results indicate that managers should focus on creating a favourable working environment for the employees and should be responsive to their problems. This becomes increasingly important when employees are to face multifaceted problems while discharging their duties. The businesses should work for creating an environment which will foster an increased level of satisfaction among the employees. Mayfield and Mayfield (2002) provides valuable suggestions towards leadership communication strategies that can enhance employee commitment. While feedback and communication are an important antecedent for the organization to create a fostering environment, it must also look at providing greater job satisfaction, role clarity, concern for overall well-being of employees and clear and directed feedback (Alfalla-Luque et al., 2015; Fields \& Thacker, 1992; Meyer, 2014). This will in turn enhance employee commitment to the organization and as indicated by $\mathrm{H} 2$ improve the overall organizational performance. Similarly, to cope with problems associated with inadequate infrastructure and anxieties associated with disrupting incidences, managers need to invest in establishing an integrated supply chain mechanism as this will improve organizational performance and create a competitive advantage for the organization. In addition, the integrated supply chain will also help cater to the difficulties arising from underdeveloped infrastructure and organizations will be more responsive and efficient in establishing relations with suppliers and customers. While the paper emphasized the role of these constructs within the KP region, the results also offer important contribution to overall literature in general and conflict regions EC, SCI and OP in particular. As the settings in most conflict regions are similar to KP region, i.e. increased incidences of anxiety created by war, crumbling and/or collapsed infrastructure.

We are of the opinion that research presented here can help in enhancing knowledge about the relationship between the three constructs within the KP region and open up new venues for the researcher to build upon the knowledge. At the same time, it is recommended that the future research in the area should focus on the organization that only operates within the territorial limits of $\mathrm{KP}$, which will provide a more accurate picture. Also, studies with larger sample size should be conducted to check the results of this study. It is also worthwhile to mention that while this study took data from all FMCGs operating in KP without consideration of whether the 
organization faced any untoward incidence of terrorism directly, a study with only organization that have been affected by terrorism would give a much clearer result.

\section{References}

Abbas, S. A., Hassan, A., \& Ali, S. (2017). Impact of terrorism on the development of posttraumatic stress disorder (PTSD) among the residents of Khyber Bazaar and its immediate surrounding areas in Peshawar, Khyber Pakhtunkhwa, Pakistan. Pakistan Journal of Pharmaceutical Sciences, 30(1).

Ageron, B., Gunasekaran, A., \& Spalanzani, A. (2012). Sustainable supply management: An empirical study. International Journal of Production Economics, 140(1), 168-182.

Alfalla-Luque, R., Marin-Garcia, J. A., \& Medina-Lopez, C. (2015). An analysis of the direct and mediated effects of employee commitment and supply chain integration on organisational performance. International Journal of Production Economics, 162, 242-257.

Alfalla-Luque, R., Marín-García, J. A., \& Medina-López, C. (2012). Is worker commitment necessary for achieving competitive advantage and customer satisfaction when companies use HRM and TQM practices? Universia Business Review(36).

Ali, M. A., Mahsud, N. K., \& Khan, W. (2016). War against Terrorism and its Impact on Children's Academic Performance In District Swat Khyber Pakhtunkhwa Pakistan. Journal Of Management Info, 9(1), 12-20.

Anderson, J. C., \& Gerbing, D. W. (1988). Structural equation modeling in practice: A review and recommended two-step approach. Psychological Bulletin, 103(3), 411-427.

Autry, C. W., Rose, W. J., \& Bell, J. E. (2014). Reconsidering the supply chain integration-performance relationship: in search of theoretical consistency and clarity. Journal of Business logistics, 35(3), 275-276.

Bader, A. K., Reade, C., \& Froese, F. J. (2016). Terrorism and expatriate withdrawal cognitions: the differential role of perceived work and non-work constraints. The International Journal of Human Resource Management, 1-25.

Bardoel, E. A., Pettit, T. M., De Cieri, H., \& McMillan, L. (2014). Employee resilience: an emerging challenge for HRM. Asia Pacific Journal of Human Resources, 52(3), 279-297.

Barratt, M. (2004). Understanding the meaning of collaboration in the supply chain. Supply chain management: An international journal, 9(1), 30-42.

Bowersox, D. J., Closs, D. J., \& Stank, T. P. (2003). How to master cross enterprise collaboration. Supply Chain Management Review, 7(4), 18-27.

Byrne, B. M. (2013). Structural equation modeling with LISREL, PRELIS, and SIMPLIS: Basic concepts, applications, and programming. New York: Psychology Press.

Cadden, T., Marshall, D., \& Cao, G. (2013). Opposites attract: organisational culture and supply chain 
performance. Supply chain management: An International Journal, 18(1), 86-103.

Cao, Z., Huo, B., Li, Y., \& Zhao, X. (2015). The impact of organizational culture on supply chain integration: a contingency and configuration approach. Supply chain management: An International Journal, 20(1), 24-41.

Christopher, M., \& Juttner, U. (2000). Supply chain relationships: Making the transition to closer integration. International Journal of Logistics, 3(1), 5-23.

Christopher, M., \& Jüttner, U. (2000). Developing strategic partnerships in the supply chain: a practitioner perspective. European Journal of Purchasing $\mathcal{E}$ Supply Management, 6(2), 117-127.

Crum, M., Poist, R., Carter, C. R., \& Liane Easton, P. (2011). Sustainable supply chain management: Evolution and future directions. International Journal of Physical Distribution $\mathcal{E}$ Logistics Management, 41(1), 46-62.

Dainty, A. R., Millett, S. J., \& Briscoe, G. H. (2001). New perspectives on construction supply chain integration. Supply chain management: An International Journal, 6(4), 163-173.

Danese, P., \& Bortolotti, T. (2014). Supply chain integration patterns and operational performance: A plant-level survey-based analysis. International Journal of Production Research, 52(23), 7062-7083.

Elorza, U., Aritzeta, A., \& Ayestaran, S. (2011). Exploring the black box in Spanish firms: the effect of the actual and perceived system on employees' commitment and organizational performance. International Journal of Human Resource Management, 22(7), 1401-1422.

Estampe, D., Lamouri, S., Paris, J.-L., \& Brahim-Djelloul, S. (2013). A framework for analysing supply chain performance evaluation models. International Journal of Production Economics, 142(2), 247-258.

Fabbe-Costes, N., \& Jahre, M. (2008). Supply chain integration and performance: A review of the evidence. The International Journal of Logistics Management, 19(2), 130-154.

Fawcett, S. E., \& Magnan, G. M. (2002). The rhetoric and reality of supply chain integration. International Journal of Physical Distribution $\mathcal{E}$ Logistics Management, 32(5), 339-361.

Fawcett, S. E., Magnan, G. M., \& McCarter, M. W. (2008). Benefits, barriers and bridges to effective supply chain management. Supply Chain Management: An international Journal, 13(1), 35-48.

Fields, M. W., \& Thacker, J. W. (1992). Influence of quality of work life on company and union commitment. Academy of Management Journal, 35(2), 439-450.

Fine, C. H. (1998). Clockspeed: The winning industry control in the age of temporary advantage. Reading, MA: Perseus Books.

Flynn, A., Chan, K. W., Zhu, Z. H., \& Yu, L. (2017). Sustainability, space and supply chains: The role of bamboo in Anji County, China. Journal of Rural Studies, 49, 128-139.

Fornell, C., \& Larcker, D. F. (1981). Evaluating structural equation models with unobservable variables 
and measurement error. Journal of Marketing Research, 18(1), 39-50.

Frohlich, M. T., \& Westbrook, R. (2001). Arcs of integration: an international study of supply chain strategies. Journal of Operations Management, 19(2), 185-200.

Gaertner, S. (2000). Structural determinants of job satisfaction and organizational commitment in turnover models. Human Resource Management Review, 9(4), 479-493.

Gimenez, C., \& Ventura, E. (2003). Supply chain management as a competitive advantage in the Spanish grocery sector. The International Journal of Logistics Management, 14(1), 77-88.

Gowen Iii, C. R., \& Tallon, W. J. (2003). Enhancing supply chain practices through human resource management. Journal of Management Development, 22(1), 32-44.

Guest, D. E., \& Conway, N. (2002). Communicating the psychological contract: An employer perspective. Human Resource Management Journal, 12(2), 22-38.

Hair, J. F., Black, W. C., Babin, B. J., \& Anderson, R. E. (2010). Multivariate data analysis: A global perspective. Upper Saddle River, New Jersey: Pearson Education.

Handfield, R. B., \& Nichols, E. L. (2002). Supply chain redesign: Transforming supply chains into integrated value systems: FT Press.

Harrison, A., \& Van Hoek, R. (2005). Logistics management and strategy. Harlow, England: Pearson Education.

Hertz, S. (2001). Dynamics of alliances in highly integrated supply chain networks. International Journal of Logistics, 4(2), 237-256.

Huang, M.-C., Yen, G.-F., \& Liu, T.-C. (2014). Reexamining supply chain integration and the supplier's performance relationships under uncertainty. Supply chain management: An International Journal, 19(1), 64-78.

Jin, Y., Vonderembse, M., Ragu-Nathan, T., \& Smith, J. T. (2014). Exploring relationships among IT-enabled sharing capability, supply chain flexibility, and competitive performance. International Journal of Production Economics, 153, 24-34.

Kline, R. B. (2011). Principles and practice of structural equation modeling. New York: The Guilford press.

Kuo, T.-H., Ho, L.-A., Lin, C., \& Lai, K.-K. (2010). Employee empowerment in a technology advanced work environment. Industrial Management $\mathcal{E}$ Data Systems, 110(1), 24-42.

Lambert, D. M., Cooper, M. C., \& Pagh, J. D. (1998). Supply chain management: implementation issues and research opportunities. The International Journal of Logistics Management, 9(2), 1-20.

Leuschner, R., Rogers, D. S., \& Charvet, F. F. (2013). A metalanalysis of supply chain integration and firm performance. Journal of Supply Chain Management, 49(2), 34-57.

Li, S., Ragu-Nathan, B., Ragu-Nathan, T. S., \& Subba Rao, S. (2006). The impact of supply chain man- 
agement practices on competitive advantage and organizational performance. Omega, 34(2), 107-124.

Mackelprang, A. W., Robinson, J. L., Bernardes, E., \& Webb, G. S. (2014). The relationship between strategic supply chain integration and performance: a metalanalytic evaluation and implications for supply chain management research. Journal of Business logistics, 35(1), 71-96.

Mayfield, J., \& Mayfield, M. (2002). Leader communication strategies critical paths to improving employee commitment. American Business Review, 20(2), 89.

Meyer, J. P. (2014). Employee commitment, motivation, and engagement: Exploring the links. In M. Gagné (Ed.), Oxford library of psychology. The Oxford handbook of work engagement, motivation, and self-determination theory (pp. 33-49). New York: Oxford University Press.

Meyer, J. P., Allen, N. J., \& Smith, C. A. (1993). Commitment to organizations and occupations: Extension and test of a three-component conceptualization. Journal of Applied Psychology, 78(4), 538.

Mowday, R. T., Steers, R. M., \& Porter, L. W. (1979). The measurement of organizational commitment. Journal of vocational behavior, 14(2), 224-247.

Narasimhan, R., \& Kim, S. W. (2002). Effect of supply chain integration on the relationship between diversification and performance: Evidence from Japanese and Korean firms. Journal of operations management, 20(3), 303-323.

Naz, A., Khan, W., Hussain, M., \& Daraz, U. (2011). The crises of identity: Globalization and its impacts on socio-cultural and psychological identity among Pakhtuns of Khyber Pakhtunkhwa, Pakistan. International Journal of Academic Research in Business and Social Sciences, 1(1), 1-11.

Nishii, L. H., Lepak, D. P., \& Schneider, B. (2008). Employee attributions of the "why" of HR practices: Their effects on employee attitudes and behaviors, and customer satisfaction. Personnel psychology, 61(3), 503-545.

Nunnally, J. C. (1978). Psychometric theory. New York: McGraw Hill.

Pagell, M., \& Shevchenko, A. (2014). Why research in sustainable supply chain management should have no future. Journal of supply chain management, 50(1), 44-55.

Pandey, P., Bhattacharyya, S., \& Kaur, A. (2012). Exploring the role of HR practices in supply chain. Journal of Advances in Management Research, 9(1), 113-123.

Patterson, M. G., West, M. A., Lawthom, R., \& Nickell, S. (1997). Impact of people management practices on business performance: Institute of Personnel and Development London.

Porter, M. E. (1986). Competitive advantage. New York: Free Press.

Prajogo, D., Oke, A., \& Olhager, J. (2016). Supply chain processes: Linking supply logistics integration, supply performance, lean processes and competitive performance. International Journal of Operations E Production Management, 36(2), 220-238. 
Qrunfleh, S., \& Tarafdar, M. (2014). Supply chain information systems strategy: Impacts on supply chain performance and firm performance. International Journal of Production Economics, 147, 340-350.

Ralston, P. M., Blackhurst, J., Cantor, D. E., \& Crum, M. R. (2015). A structure-conduct-performance perspective of how strategic supply chain integration affects firm performance. Journal of supply chain management, 51(2), 47-64.

Samad, S. (2013). Assessing the contribution of human capital on business performance. International Journal of Trade, Economics and Finance, 4(6), 393.

Shub, A. N., \& Stonebraker, P. W. (2009). The human impact on supply chains: evaluating the importance of "soft" areas on integration and performance. Supply chain management: An international journal, 14(1), 31-40.

Sofyalığlu, Ç., \& Öztürk, Ş. (2012). Meta analysis of the relationship between supply chain integration dimensions and firm performance. European Journal of Economics, Finance and Administrative Sciences, 52(September), 99-119.

Stevens, G. C. (1989). Integrating the supply chain. International Journal of Physical Distribution $\mathcal{E}$ Materials Management, 19(8), 3-8.

Stevens, G. C., \& Johnson, M. (2015). Integrating the supply chain ... 25 years on. International Journal of Physical Distribution $\mathcal{E}$ Logistics Management, 46(1), 19-42.

Stock, J. R., \& Boyer, S. L. (2009). Developing a consensus definition of supply chain management: a qualitative study. International Journal of Physical Distribution $\mathcal{E}$ Logistics Management, 39(8), 690-711.

Swink, M., Narasimhan, R., \& Wang, C. (2007). Managing beyond the factory walls: Effects of four types of strategic integration on manufacturing plant performance. Journal of operations management, 25(1), 148-164.

Tan, K. C. (2001). A framework of supply chain management literature. uropean Journal of Purchasing and Supply Management, 7(1), 39-48.

Vanichchinchai, A. (2012). The relationship between employee involvement, partnership management and supply performance: Findings from a developing country. International Journal of Productivity and Performance Management, 61(2), 157-172.

Weston, R. (2006). A brief guide to structural equation modelling. The Counseling Psychologist, 34(5), 719-751.

Wiengarten, F., Humphreys, P., Gimenez, C., \& McIvor, R. (2016). Risk, risk management practices, and the success of supply chain integration. International Journal of Production Economics, 171, 361-370.

Zhao, X., Huo, B., Flynn, B. B., \& Yeung, J. H. Y. (2008). The impact of power and relationship commitment on the integration between manufacturers and customers in a supply chain. Journal of Operations Management, 26(3), 368-388. 